\title{
Prevalence of Nursing Diagnostics in Oil Industry Workers in Bahia, Brazil
}

\author{
Prevalência de diagnósticos de \\ enfermagem em trabalhadores da indústria \\ de petróleo na Bahia, Brasil
}

\author{
Lilian Monteiro Ferrari Viterbo' ${ }^{1}$ \\ Ingrid Bonfim Silva ${ }^{2}$ \\ Jamile Santos Ferreira Leite ${ }^{3}$ (1) \\ Diogo Guedes Vidal 4 (1) \\ Andreia de Moura5 (1) \\ Maria Alzira Pimenta Dinis ${ }^{6}$ (1)
}

\begin{abstract}
${ }^{1}$ Corresponding author. FP-ENAS, Universidade Fernando Pessoa (Porto). Portugal. lilianmferrari@gmail.com 2,3Universidade Federal da Bahia (Salvador). Bahia, Brazil. ingridbonfimsilva@hotmail.com, jamyle_ferreira@hotmail.com 4,6FP-ENAS, Universidade Fernando Pessoa (Porto).Portugal. diogoguedesvidal@hotmail.com, madinis@ufp.edu.pt 5Universidade Lusófona do Porto (Porto). Portugal. andreia.moura@ulp.pt
\end{abstract}

\begin{abstract}
OBJECTIVE: to describe the prevalence of nursing diagnostics and to analyse differences between the groups according to the indicator created from the diagnoses and intervention of the CIPE $®$ relating to job satisfaction. METHOD: 869 workers attending the occupational health assessments of an oil industry with nurse practitioners, using a data collection form to support clinical reasoning in the definition of diagnostics and intervention, with CIPE®. Data collected were grouped into five indicators: food aspects, interpersonal relationships, physical health, health behaviours and working conditions. RESULTS: 13 types of diagnoses and 18 interventions were mapped, being the most prevalent "job satisfaction" (85.0 \%) and "promoting healthy relationship and communication techniques" (76.3 $\%)$, respectively. The student's t-test was used to compare scores of the five indicators between the groups. The "satisfied at work" revealed better interpersonal relationships $(p<0.001)$. The group intervened with the initiative "to promote healthy relationships and communication techniques and to encourage healthy relationships" demonstrates better interpersonal relationships $(p<0.01)$ and better physical health $(p<0.05)$. The best working conditions $(p<0.01)$ were identified in the group subject to "other interventions". CONCLUSION: structured performance of the nurse practitioner in the worker healthcare enables the development of strategies aimed at implementing improvements within organizational aspects of the nursing work.
\end{abstract}

DESCRIPTORS: Nursing. Occupational health. Standardized nursing terminology.
RESUMO | OBJETIVO: descrever a prevalência de diagnóstico de enfermagem e analisar diferenças entre os grupos segundo o indicador criado a partir dos diagnósticos e intervenção da CIPE $®$ relativas à satisfação do trabalho. MÉTODO: 869 trabalhadores participaram das avaliações de saúde ocupacional de uma indústria petrolífera com enfermeiros, utilizando um formulário de coleta de dados para apoiar o raciocínio clínico na definição de diagnóstico e intervenção, com CIPE $®$. Os dados coletados foram agrupados em cinco indicadores: aspectos alimentares, relações interpessoais, saúde física, comportamentos de saúde e condições de trabalho. RESULTADOS: foram mapeados 13 tipos de diagnósticos e 18 intervenções, sendo os mais prevalentes "satisfação no trabalho" $(85,0 \%)$ e "promover técnicas saudáveis de relacionamento e comunicação" (76,3 \%), respectivamente. $O$ teste $t$ foi utilizado para comparar os escores dos cinco indicadores entre os grupos. $\mathrm{O}$ "satisfeito no trabalho", revelou melhores relações interpessoais $(p<0,001)$. $O$ grupo intervencionado com a iniciativa "promover técnicas saudáveis de relacionamento e comunicação e incentivar relações saudáveis"," demonstra melhores relações interpessoais $(p<0,01)$ e melhor saúde física $(p<0,05)$. As melhores condições de trabalho $(p<0,01)$ foram identificadas no grupo sujeito a "outras intervenções". CONCLUSÃO: o desempenho estruturado do enfermeiro na área da saúde do trabalhador possibilita o desenvolvimento de estratégias voltadas à implementação de melhorias nos aspectos organizacionais do trabalho de enfermagem.

DESCRITORES: Enfermagem. Saúde Ocupacional. Terminologia padronizada de enfermagem. 


\section{Introduction}

The world of work has changed in the last century, affecting workers in their multiple dimensions ${ }^{1}$. There have been changes in the concepts, goals, objectives and in the way of seeing and performing the task in the specific context of work. Work has been shaping the new configurations of reality and society, thus adapting to the emerging requirements. As a result, organizations are increasingly committed to creating a dynamism that facilitates evolution, productivity and economy, in ways that allow optimizing the time and scope of defined goals ${ }^{2}$. It is not just about new tasks or functions, involving new competences, different ways of performing and organizing work, which contribute to shape and modify the relationships between the worker and the work environment ${ }^{1}$.

In such a scenario, job satisfaction has been identified as a relevant factor influencing the worker, which can manifest on health, quality of life and behaviour, with important consequences for individuals and organizations ${ }^{3}$. The Theory of Work Satisfaction ${ }^{4}$ is based on two pillars: the importance given by the worker to the goal to be achieved; and the motivation that drives the individual to act (performance) to obtain the results (satisfaction), i.e., a pleasurable emotional state, resulting from the positive assessment of the reality of the work, concerning the values of the individual. On the other hand, dissatisfaction is the opposite, resulting from the negative assessment of the same reality, in comparison with the personal values of the worker. Thus, work is one of human being's ways of positioning as a single individual, and undeniably, one of the components of happiness ${ }^{5}$, resulting from the full satisfaction of psychosocial needs, the feeling of pleasure and the sense of contribution in the exercise of professional activity. It is one of the organizing axes of social life, acting as a determinant of people's living conditions and health.

A brief review of the state of the art has revealed a growing concern by the employer ${ }^{-6-z}$ to realize how satisfied workers are. Associated with this factor, is the degree of productivity, although exclusively focused on the offshore context of the oil industry. A study developed by Ullberg and Torbjøsrn ${ }^{8}$ in an offshore oil industry found that, associated with absenteeism, issues such as job dissatisfaction and stress suggesting a higher investment by companies in the social and organizational factors that should be the basis of health promotion. Another study by Dickey et al. .9 suggests that the companies should provide promotion and training skills for workers, aiming to reduce absenteeism and job dissatisfaction.

Parallel to changes in technologies and ways of organizing work, there has been a significant evolution of the concept of health and the struggle to ensure that the world of work is not a source of suffering, illness, injury and death ${ }^{10}$. Therefore, the transformation of productive processes must take place to make them health promoters, instead of promoting sickness and death. In this field of health, there is a diversity of knowledge that enables collective, interdisciplinary and intersectoral interventions ${ }^{11}$. The principle of the worker's integral health invokes the right to health in an unrestricted sense of full citizenship, including actions of health promotion, prevention and assistance, in an integrated manner, with the broad and effective participation of workers, professionals and researchers, educational institutions, union representatives, services, civil society and other institutional and social actors. This concept is in constant transformation, since the health problems caused by the work activity change with the work itself, conditioning the understanding, in time and space, of the notion of health ${ }^{1}$. Accordingly, the role of the professional in the worker's health (WH) field is multidimensional, established in a network of interactions, and it is important to consider the objectivity and subjectivity inherent to health at work, considering that the object that constitutes it is human beings whose technical interventions are permeated by interpersonal relationships.

In this scenario, the nurse practitioner has been gaining space in organizations, as long as they can work on workers' quality of life, protection against chemical, physical, biological and psychosocial agents, health maintenance, occupational or nonoccupational diseases, and in rehabilitation for work $^{12-13}$. The Systematization of Nursing Care (SNC) is a methodology for organizing and systematizing healthcare, based on the principles of the scientific method (Figure 1), aiming to identify health-disease situations and nursing care needs, as well as to subsidize interventions for the promotion, prevention, recovery and rehabilitation of individual, family and community health ${ }^{14-15}$. 


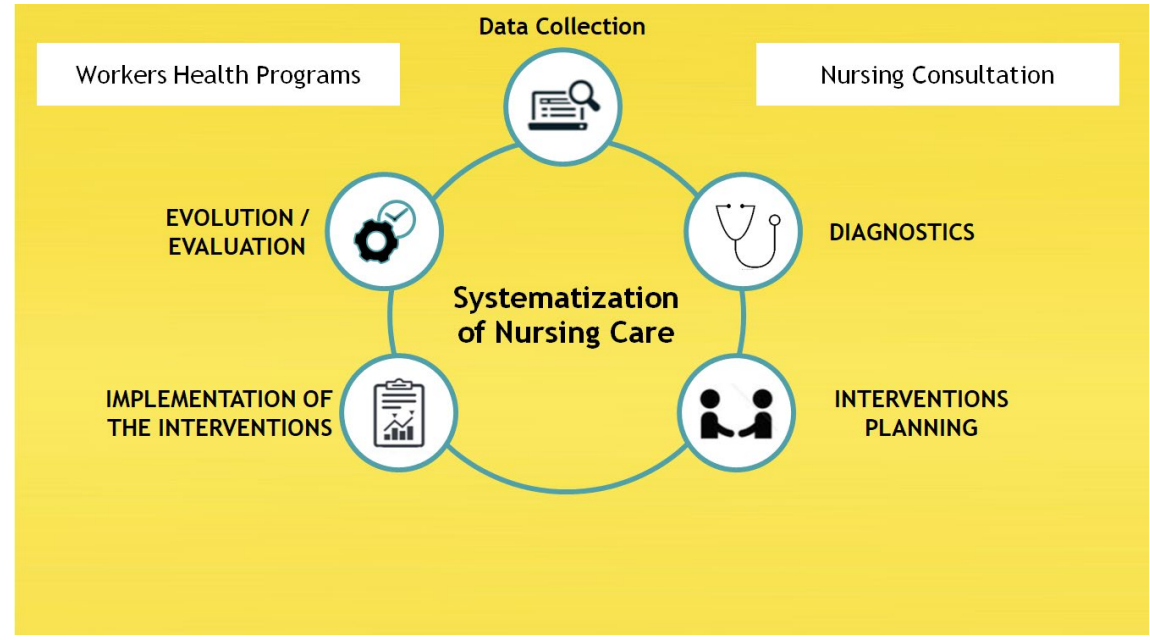

Also, the International Classification for Nursing Practice - CIPE® ${ }^{16}$ terminology - consists of an information system that classifies nursing phenomena, actions and results, allowing the description and characterization of nursing practice. It represents a unifying framework for all classification systems available worldwide. The CIPE $®$ terminology instrumentalizes the SNC at work, making it possible to assess the health situation of the workers, the epidemiological analyses, as well as the contribution to the development of health policies and the planning of care. Recent studies by Calvacante et al. ${ }^{17}$ and Rabelo-Silva et al. $\frac{18}{8}$ reinforce the importance of the practice of using diagnostics and interventions in several areas of nursing, and the lack of knowledge related to the use of $\mathrm{CIPE} \circledast$ in the $\mathrm{WH}$ field is seen as a knowledge gap that needs to be addressed in the oil industry of today.

This study aims to contribute to the development of strategies focused on implementing improvements to the organizational aspects of the nursing work, namely in the job satisfaction field. Therefore, it is intended to describe the prevalence of nursing diagnoses and to analyse if there are significant differences between groups according to the indicator created from the diagnoses and interventions of the CIPE applied in nursing consultations during the periodic examination of the occupational health service of an oil industry, Bahia, Brazil.

\section{Materials and Methods}

\section{Study design}

This is a cross-sectional, descriptive study, conducted at the occupational health service of an oil industry in Bahia, Brazil, from February to November 2017. 869 oil Brazilian workers attended by nurse practitioners with a direct employment relationship with the oil company were included in the research. Workers with no direct employment relationship with the oil company were excluded from the present study.

Workers attended the occupational health service to perform the annual periodic examination, which in addition to the medical assessments provided by law had the participation of occupational nurses to carry out consultations, with a focus on preventing injuries and promoting health. For standardization of healthcare, the 6 nurses of the service prepared a semi-structured interview script, based on the Interdisciplinary Worker's Health Approach Instrument (IWHAI) ${ }^{19}$, already published, which addresses the social characteristics of workers, socioenvironmental components, personal characteristics, level of self-care, environmental components, exposure to risk agents, health surveillance, family relationships and relationships in the workplace Table 1 shows the IWHAI indicator which varies on a scale from 0 to 4 , with 0 meaning non-existent or inadequate and 4 an optimal index. 
Table 1. Semi-structured interview script for consultation with the occupational nurse, Salvador, Bahia, Brazil, 2017

\begin{tabular}{|c|c|c|}
\hline Dimension & Domain & Parameter \\
\hline \multirow[b]{3}{*}{$\begin{array}{l}\text { Working Conditions Related } \\
\text { Factors }\end{array}$} & Work environment relationships & $\begin{array}{l}\text { Refers to a stable relationship in the work } \\
\text { environment and does not identify health } \\
\text { interferences }\end{array}$ \\
\hline & Ergonomic Aspects & $\begin{array}{l}\text { Adapted post/work area, assessed by } \\
\text { ergonomists (task and activity analysis), } \\
\text { provides adequate posture, no pain } \\
\text { complaints }\end{array}$ \\
\hline & Exposure to Risk Agents & $\begin{array}{l}\text { Exposure equal to or less than the } \\
\text { tolerance limit or exposure above the } \\
\text { tolerance limit with the use of protective } \\
\text { equipment, with biological training and/or } \\
\text { monitoring, when applicable }\end{array}$ \\
\hline Behavioural Factors & Self-care level & $\begin{array}{c}\text { Healthcare, understands and uses } \\
\text { available resources to improve health } \\
\text { status regularly }\end{array}$ \\
\hline Personal Factors & Personal Factors & $\begin{array}{l}\text { Healthy; Does not have chronic diseases; } \\
\text { Irrelevant pathologies }\end{array}$ \\
\hline $\begin{array}{l}\text { Social and Community } \\
\text { Networks Factors }\end{array}$ & Social aspects & $\begin{array}{l}\text { Uses leisure and/or spirituality and/or } \\
\text { social environments to promote health } \\
\text { and realizes this need, in addition to } \\
\text { positively reflecting on health }\end{array}$ \\
\hline
\end{tabular}

Source: Adapted from Viterbo et al. ${ }^{19}$

During the study period, consultations were held by 4 of the 6 nurses, with specific training in ergonomics and mental health. Examinations were carried out in appropriate rooms, with an average duration of 30 minutes and the interview script was applied in this context. For each identified health domain, the respective nursing diagnoses and interventions were defined by the same nurses, using the terminology CIPE $®$ as taxonomy.

For the development of the investigation, the researchers requested information from the institution's electronic medical records, which included the data collected by nurses during the periodic exam consultations. The database obtained was treated intending to standardize the names of the variables and, subsequently, a randomly generated code was created to guarantee the anonymity of the study participants. The information collected was grouped into five indicators for data analysis, as shown in Table 2. 
Table 2. Indicators and the corresponding aggregated variables, Salvador, Brazil, 2017

\begin{tabular}{|c|c|}
\hline Indicators & Variables \\
\hline Food aspects & $\begin{array}{c}\text { simple carbohydrate } \\
\text { fibres } \\
\text { saturated lipids } \\
\text { liquids } \\
\text { sodium mineral }\end{array}$ \\
\hline Interpersonal relationships & $\begin{array}{c}\text { social characteristics } \\
\text { socio-environmental components } \\
\text { family relationships } \\
\text { work place relationships }\end{array}$ \\
\hline Physical aspects & $\begin{array}{c}\text { flexibility } \\
\text { abdominal strength } \\
\text { arm strength } \\
\text { oral hygiene } \\
\text { pain during physical activity } \\
\text { diabetes mellitus } \\
\text { altered glycaemia } \\
\text { hypertension } \\
\text { altered blood pressure } \\
\text { dyslipidaemia } \\
\text { weight } \\
\text { periodontal community index }\end{array}$ \\
\hline Health behaviours & $\begin{array}{l}\text { alcohol consumption* } \\
\text { food choice } \\
\text { smoke } \\
\text { oral hygiene } \\
\text { level of physical activity } \\
\text { self-care level }\end{array}$ \\
\hline Working conditions & $\begin{array}{l}\text { environmental components } \\
\text { exposure to risk agents } \\
\text { health surveillance } \\
\text { food security }\end{array}$ \\
\hline
\end{tabular}

*World Health Organization ${ }^{20}$ criteria were used as a reference for consumption pattern analyses. Source: Elaborated by the authors.

\section{Statistical Analysis}

Statistical analyses were performed in SPSS version 25 for Windows. Among the aspects investigated in Table 1, the dimension "Factors Related to Working Conditions", which comprises aspects related to: i) work environment relationships, ii) ergonomic aspects, iii) exposure to risk agents and iv) health surveillance, was established to be the focus of this study. In line with this, the prevalence of each domain was analysed and the study of "Relations in the Work Environment" was delineated. The scale of this domain was specified as follows: 0 - refers to a conflictive, permanent relationship in the work environment that interferes with the worker's health, 1 - refers to a relationship in the work environment that causes specific mobilizations and identifies interferences in the worker's health in this period, 2 - refers to relationship in the mobilizing work environment at specific moments and does not identify interferences in the worker's health, 3 - refers to a relationship in the stable work environment and does not identify interferences in the worker's health and 4 - the same previous condition and encourages healthy habits in the work environment. Based on the findings of the diagnoses and interventions, the participants were divided into four different groups, with Groups I, "Satisfied in the work environment", considering respondents 0 and 2 of the scale and II, "Dissatisfied in the work environment", considering respondents 3 and 4 of the scale related to the diagnoses found and Groups III, "Promoting healthy communication techniques and encouraging healthy relationship policies" and IV, "Other interventions", related to the interventions. Groups II and IV aggregate all diagnoses and interventions differing from those defined in Groups I and III, respectively. 
Student's t-test for independent samples was applied to compare the scores calculated between the groups and the five considered indicators: food aspects, interpersonal relationships, physical health, health behaviours and working conditions. The construction of the indicators followed the transformation of the variables composing them into total scores through the SPSS. Scores were calculated based on the sum of the indices (0-4) attributed to each variable integrated in an indicator (see Table 2). The scores means were then calculated.

The grouping of variables followed the guidelines identified in the existing literature $3,19,21$. No comparisons were made by sex as previous studies, such as those by Dickey et al. $\underline{9}$ and Burke et al. $\underline{22}$ reveal no sex differences in job satisfaction levels of oil industry workers.

Data from Groups I, II, III and IV were subsequently compared with Table 2.

\section{Ethical Approval}

In all stages of the study, the recommendations and guidelines of Resolution 466/2012 of the Brazilian Ministry of Health on ethical aspects regulating research with human beings, were followed. The study was approved by the Research Ethics Committee of the BAHIANA School of Medicine and Public Health and CAAE no. 84318218.2.0000.5544. Before participating in the study, all subjects gave their informed consent for inclusion. The study included only a retrospective assessment of data available through an Institutional Database, and the analyses were performed as part of the periodic epidemiological assessment on occupational health and safety risks. Personal data was restricted, also considering the Ethics Committee approval, and was treated in order to guarantee the respect of privacy of the workers involved in the study.

\section{Results}

In this study a total of 869 workers completed the interview, Males $(93.0 \%)$ with a mean age of 45 years, between 23 and 72 years, prevailed. Regarding marital status, $50.5 \%$ are married, 37.9 $\%$ are single, $2.6 \%$ are divorced and $4.9 \%$ relate another state. In terms of the work regime, $52.4 \%$ work in administrative hours, followed by $25.4 \%$ with shift work. In relation to schooling, $49.6 \%$ have completed high school, $31.6 \%$ higher education, while $18.8 \%$ declared another school situation.

The nursing diagnoses of the CIPE ${ }^{\circledR}$ taxonomy related to the organizational aspects of the work were mapped, being the most prevalent: work satisfaction (85.0\%), stress overload (6.0\%) and stress due to change (or transfer) of the workplace environment (5.9\%). The other diagnostics represent $3.1 \%$, according to the data presented in Table 3.

Table 3. Nursing diagnostics of the CIPE ${ }^{\circledR}$ taxonomy related to the organizational aspects of the work, Salvador, Brazil, 2017

\begin{tabular}{ccc}
\hline CIPE® Diagnostics & $\boldsymbol{n}$ & $\%$ \\
\hline Impaired adaptation & 1 & 0.1 \\
Anxiety & 6 & 0.7 \\
Complication associated with health care & 2 & 0.2 \\
Discomfort & 1 & 0.1 \\
Stress due to change (or transfer) of the environment & 51 & 5.9 \\
Relationship problem & 5 & 0.6 \\
Risk of low self-esteem, situational & 1 & 0.1 \\
Risk of dissatisfaction with health care & 2 & 0.2 \\
Impaired sleep risk & 7 & 0.8 \\
Job satisfaction & 739 & 85.0 \\
Stress overload & 52 & 6.0 \\
Impaired socialization & 1 & 0.1 \\
Night shift work & 1 & 0.1 \\
\hline Total & 869 & 100.0 \\
\hline
\end{tabular}

Source: Elaborated by the authors. 
From the data analysed, the nursing interventions of the CIPE® taxonomy related to the organizational aspects of the work were identified, being the most prevalent: promoting healthy relationships and communication techniques (76.3\%), encouraging healthy relationship policies (6.4\%), assessing the characteristics of stress (5.1\%) and to obtain data on ability to manage stress (3.7\%). The other interventions represent a percentage of $8.5 \%$, according to the data detailed in Table 4.

Table 4. Nursing interventions of the CIPE® taxonomy related to the organizational aspects of work, Salvador, Brazil, 2017

\begin{tabular}{ccc}
\hline CIPE® Interventions & $\boldsymbol{n}$ & $\%$ \\
\hline Assess the characteristics of stress & 44 & 5.1 \\
Advise the patient & 1 & 0.1 \\
Assess behaviour against adaptation & 3 & 0.3 \\
Assess satisfaction with health care & 3 & 0.3 \\
Collaborate with the actions developed by health promotion services & 1 & 0.1 \\
Listen to the worker & 1 & 0.1 \\
Manage anxiety & 2 & 0.2 \\
Manage negative behaviour & 1 & 0.1 \\
Implementing fun and leisure activities for workers and family members & 25 & 2.9 \\
Encourage healthy relationship policies & 56 & 6.4 \\
Collect data on anxiety & 5 & 0.6 \\
Collect data on ability to manage stress & 32 & 3.7 \\
Collect data on stress level & 3 & 0.3 \\
Collect data on sleep & 4 & 0.5 \\
Orient on sleep & 22 & 2.5 \\
Pridance on management (control) of stress & 2 & 0.2 \\
Provide bedtime routine & 1 & 0.1 \\
Promote healthy relationships and communication techniques & 663 & 76.3 \\
\hline Total & 869 & 100 \\
\hline Source: Elaborated by the authors. & &
\end{tabular}

Table 5 shows the results between Groups I and Group II, using the indicators outlined in Table 2.

Table 5. Relationship between the satisfied workers (Group I) versus the unsatisfied workers (Group II) and the studied indicators, Salvador, Brazil, 2017

\begin{tabular}{|c|c|c|c|c|c|}
\hline Indicators & \multicolumn{2}{|c|}{$\begin{array}{c}\text { Satisfied in the work } \\
\text { environment } \\
\text { Group I }(n=739)\end{array}$} & \multicolumn{2}{|c|}{$\begin{array}{c}\text { Unsatisfied in the work } \\
\text { environment } \\
\text { Group II }(n=130)\end{array}$} & $t$ \\
\hline Food Aspects & 13.6 & 1.60 & 13.5 & 1.77 & -0.656 \\
\hline Interpersonal Relationships & 13.5 & 1.96 & 11.9 & 2.27 & $-7.365 * * \star$ \\
\hline Physical health & 43.8 & 7.40 & 42.9 & 6.73 & -0.971 \\
\hline Working conditions & 12.2 & 1.25 & 12.3 & 1.13 & 0.797 \\
\hline
\end{tabular}

Note: $* * \star p<0.001 ; M=$ Mean; $S t D=$ Standard Deviation; $t=t$-test result.

The workers who are more satisfied with their workplace are also those reporting better interpersonal relationships $(p<0.001)$, as shown in table 5 , where the total score of the indicators was used.

Table 6 shows the results between Groups III and Group IV, using the indicators outlined in Table 2. 


\begin{tabular}{cccccc}
\hline & $\begin{array}{c}\text { Promotion of healthy } \\
\text { communication techniques and } \\
\text { encouragement of healthy } \\
\text { relationship policies } \\
\text { Group III }(\boldsymbol{n}=\mathbf{7 1 9})\end{array}$ & $\begin{array}{c}\text { Other interventions } \\
\text { Group IV } \\
(\boldsymbol{n}=\mathbf{1 5 0})\end{array}$ & $\boldsymbol{M}$ & $\boldsymbol{S t \boldsymbol { D }}$ & $\boldsymbol{t}$ \\
\hline & $\boldsymbol{M}$ & $\boldsymbol{S t \boldsymbol { D }}$ & 13.4 & 1.80 & -1.606 \\
\hline Food aspects & 13.6 & 1.58 & 12.9 & 2.75 & $-2.738^{* *}$ \\
Interpersonal relationships & 13.4 & 1.91 & 42.0 & 7.35 & $-2.330^{*}$ \\
Physical health & 44.0 & 7.29 & 19.9 & 3.15 & -.188 \\
Health behaviours & 20.1 & 3.38 & 12.5 & 1.34 & $3.114^{* *}$ \\
Working conditions & 12.1 & 1.21 & &
\end{tabular}

Better interpersonal relationships ( $p<0.01$ ), better physical health conditions $(p<0.05)$, and better working conditions $(p<0.01)$ were also reported among workers who received intervention in promotion of healthy relational and communication techniques and encouragement of healthy relationships, as shown in table 6.

\section{Discussion}

According to Brazilian last census (2010), the city of Salvador, Bahia, Brazil, with an area of 693831 $\mathrm{km}^{2}$, has 2.675 .656 million of inhabitants. $51.9 \%$ are females, $28.6 \%$ of the population works and the schooling rate from 6 to 14 years of age is $95.9 \%$. In this study, workers are mostly male (93.0\%), related to a traditional prevalence of this sex in this industry, and have completed high school (49.6\%).

The Theory of Job Satisfaction ${ }^{4}$ is based on two main aspects that involve the emphasis of workers to achieve company goals and the motivation that leads individuals to act to obtain results. The Table 3 presented the CIPE $₫$ taxonomy nursing diagnoses related to the organizational aspects of the work investigated and it can be observed that the highest percentage of participants reported being satisfied with the workplace $(85.0 \%)$. Job satisfaction was identified as a relevant factor that affects workers and can be reflected in health, quality of life and behavior ${ }^{3}$. This satisfaction represents one of the determining factors for the fullness of the human being, because when the worker is able to develop work with pleasure, living with feelings of recognition and appreciation, the work environment becomes a place of growth and satisfaction $\stackrel{23,24}{2}$. Another relevant aspect demonstrated in the findings presented in Table 3 were the diagnoses "Stress overload" (6.0 $\%)$ and "Stress due to change (or transfer) of the environment" (5.9\%), related to changes in the world of work, involving new tasks, skills and different ways of executing and organizing work to meet increasingly challenging productivity goals $\mathrm{s}^{1,2}$.

Table 4 shows the nursing interventions of the CIPE $®$ taxonomy related to the organizational aspects of work. The most prevalent interventions were the "Promote healthy relationships and communication techniques" (76.3\%), followed by the "Encourage healthy relationship policies" (6.4\%). The study by Dickey et al. 9 suggests that companies offer promotion and training skills to workers, with the aim of reducing absenteeism and job dissatisfaction. Other important results found were "Assess the characteristics of stress" (5.1\%) and "Collect data on ability to manage stress" (3.7\%). Job dissatisfaction results from the individual's negative assessment of work reality, compared to his personal values ${ }^{4}$ and a study developed in the oil industry by Ulleberg and Rundmo ${ }^{8}$ suggests its association with absenteeism and stress. Accordingly, it is particularly recommended that companies invest more in social factors and organizational factors that should serve as a basis for health promotion.

As shown by the results in Table 5, allowing to analyse the relationship between satisfied, dissatisfied workers and the indicators studied, there are significant differences in interpersonal relationships between the group of satisfied workers in their workplace (Group I) and the other diagnoses associated with non-adaptation (Group II). The most satisfied subjects are those who report the best quality in their interpersonal relationships, 
whether they are socioenvironmental, family or work environment relationships. This result is in line with what has already been identified in other studies in oil industry area ${ }^{z-9}$, namely the occurrence of better physical health quality in satisfied individuals. In unsatisfied individuals, previous studies,$\frac{3,25}{\text { point out }}$ to the occurrence of health problems such as fatigue, respiratory distress, headache, digestive problems, increased cholesterol, heart disease and muscle pain, thus highlighting that being unsatisfied at work increases the probability to developed certain diseases.

Along with technological changes and the ways in which work is organized, the concept of health evolves in search of ensuring that it is not a cause of suffering, disease and death ${ }^{10}$. The results in Table 6 demonstrate that workers intervened in order to promote healthy policies and communication (Group III) report better quality in their interpersonal relationships, physical health and working conditions, than those involved in other interventions (Group IV). Collective, interdisciplinary and intersectoral interventions ${ }^{11}$ in companies enable the $\mathrm{WH}$ prevention and promotion, as well as the reduction of absenteeism and job dissatisfaction?

Although the association between job satisfaction and the health of individuals is scientifically recognized ${ }^{3}$, there are still gaps to be filled, such as the lack of attention paid to the multidimensional aspects of job satisfaction, as well as the limited number of studies that consider occupational health as a result of the articulation between physical and psychic factors.

\section{Conclusions}

The importance of the application of the CIPE $®$ terminology is based on its high level of objectivity in nursing diagnostics, allowing the design of interventions directed to the specific needs of individuals in the organizational context of work. This potentiality makes the interventions efficient and effective, promoting the maintenance of individuals' health and their productivity.
In the present study, the 13 nursing diagnostics identified of the CIPE $\AA$ taxonomy related to the organizational aspects were decisive in determining the 18 interventions to be applied. The prevalence of workers satisfied with work stands out, an important result that also leads to higher productivity and a healthier overall health condition. On the other hand, the initiative "Promotion of healthy communication techniques and encouragement of healthy relationship policies" prevails in the interventions. This particular initiative has resulted in the identification that healthier workers are effectively those with better interpersonal relationships and better physical health.

The potential of nurses' performance and the application of CIPE $₫$ terminology in the organizational context of workplace environment has proved to be an effective methodology in the development of strategies aimed at the implementation of improvements regarding the organizational aspects of work in the field of $\mathrm{WH}$.

The main limitation of this study is based on the size of the sample, which does not allow to infer the results for the general population of Brazilian oil industry workers. In particular, the reported male dominance in this particular industry, conditions comparative analyses relating sex, considering the small percentage of women involved in the study.

\section{Acknowledgment}

The authors would like to thank to the Portuguese Foundation for Science and Technology (FCT) in the scope of FCT Project UID/ Multi/04546/2019.

\section{Author contributions}

Viterbo LMF, Silva IB, Leite JSF participated in the conception, design, search and statistical analysis of the research data, interpretation of results, writing of the scientific article. Vidal DG participated in the statistical analysis of the research data, interpretation of the results, writing of the scientific article. Moura A participated in the statistical analysis of the research data, interpretation of the results. Dinis MAP participated in the supervision of the study and critical revision of the final version of the manuscript. 


\section{Competing interests}

No financial, legal or political competing interests with third parties (government, commercial, private foundation, etc.) were disclosed for any aspect of the submitted work (including but not limited to grants, data monitoring board, study design, manuscript preparation, statistical analysis, etc.).

\section{References}

1. Falzon P. Natureza, Objetivos e Conhecimentos da Ergonomia. In: Falzon P, editor. Ergonomia. São Paulo: Editora Blucher; 2007. P. 3-19.

2. Marques A, Tavares E, Souza J, Magalhães JA, Léllis J. A Ergonomia como um Fator Determinante no Bom Andamento da Produção: um Estudo de Caso. Anagrama. 2010;4(1):1-4.

3. Dinis MAP, Sousa HFP, Moura A, Viterbo LMF, Pinto RJ. Health Behaviors as a Mediator of the Association Between Interpersonal Relationships and Physical Health in a Workplace Context. Int J Environ Res Public Health. 2019;16(13):2392. doi: 10.3390/ ijerph16132392

4. Henne D, Locke EA. Job Dissatisfaction: What are the Consequences? Int J Psychol. 1985;20(2):221-40. doi: 10.1080/00207598508247734

5. Leite Â, Sousa HFP, Vidal DG, Dinis MAP. Finding a path for happiness in the context of sustainable development: a possible key. Int J Sustain Dev World Ecol. 2020;27:5:396-404. doi: 10.1080/13504509.2019.1708509

6. Munisteri I, Taha M. Job Satisfaction and Security in the Oil and Gas Industry: Through the Eyes of Professionals. Soc Pet Eng. 2014;10(2):10-1. doi: 10.2118/0214-010-TWA

7. Okafor A, Soltani A. Job Satisfaction in the Oil and Gas World. Soc Pet Eng. 2012;8(2):18-21. doi: 10.2118/0212-018-TWA

8. Ulleberg P, Rundmo T. Job stress, social support, job satisfaction and absenteeism among offshore oil personnel. Work Stress. 1997;11(3):215-228. doi: 10.1080/02678379708256836

9. Dickey H, Watson V, Zangelidis A. Job Satisfaction and Quit Intentions of Offshore Workers in the UK North Sea Oil and Gas Industry. Scott J Polit Econ. 2011;58(5):607-33. doi: 10.1111/j.14679485.2011.00561.x

10. Abrahão Jl, Torres CC. Entre a organização do trabalho e o sofrimento : o papel de mediação da atividade. Rev Produção. 2004;14(3):67-76. doi: 10.1590/S0103-65132004000300008
11. Minayo C, Machado JMH, Pena PGL. Saúde do Trabalhador na Sociedade Brasileira Contemporânea. Rio de Janeiro: Fiocruz; 2011.

12. Rogers B. Occupational and Environmental Health Nursing: Ethics and Professionalism. Workplace Health Saf. 2012;60(4):17781. doi: $\underline{10.1177 / 216507991206000406}$

13. International Council of Nurses. Closing the gap: Increasing access and equity. [Internet]. Geneva; 2011. Available from: http:// www.old.icn.ch/images/stories/documents/publications/ind/ indkit2011.pdf

14. Wollesen B, Menzel J, Lex H, Mattes K. The BASE-Program - A Multidimensional Approach for Health Promotion in Companies. Healthcare. 2016;4(4):91. doi: 10.3390/healthcare4040091

15. Schwarze M, Egen C, Gutenbrunner C, Schriek S. Early Workplace Intervention to Improve the Work Ability of Employees with Musculoskeletal Disorders in a German University HospitalResults of a Pilot Study. Healthcare. 2016;4(3):64. doi: 10.3390/ healthcare4030064

16. Nóbrega MML, Garcia TR. Classificação Internacional para a Prática de Enfermagem: instrumental tecnológico para a prática profissional. Rev Bras Enferm. 2009;62(5):758-61. doi: 10.1590/ S0034-71672009000500019

17. Cavalcante MDMA, Larocca LM, Amaral JRM. Terminology Use in Nursing Work Process in Collective Health: an Integrative Review. Rev Biosalus. 2017;2(1):1-19. doi: 10.1590/revbios. v2i1.370

18. Rabelo-Silva ER, Cavalcanti ACD, Goulart MCR, Lucena AF, Almeida M, Linch GFC et al. Advanced Nursing Process quality: Comparing the International Classification for Nursing Practice (ICNP) with the NANDA-International (NANDA-I) and Nursing Interventions Classification (NIC). J Clin Nurs. 2017;26(3-4):379-87. doi: $10.1111 /$ jocn.13387

19. Viterbo LMF, Dinis MAP, Costa AS, Vidal DG. Development and Validation of an Interdisciplinary Worker's Health Approach Instrument (IWHAI). Int J Environ Res Public Health. 2019;16(15):117. doi: $10.3390 /$ ijerph16152803

20. World Health Organization. International Guide For Monitoring Alcohol Consumption And Related Harm. Geneva; World Health Organization; 2000.

21. Benavides FG, Merino-Salazar P, Cornelio C, Assunção AA, Agudelo-Suárez AA, Amable $M$ et al. Cuestionario básico y criterios metodológicos para las Encuestas sobre Condiciones de Trabajo, Empleo y Salud en América Latina y el Caribe. Cad Saude Publica. 2016;32(9):e00210715. doi: 10.1590/0102-311×00210715 
22. Burke RJ, Matthiesen SB, Einarsen S, Fiskenbaum L, Soiland V. Gender differences in work experiences and satisfactions of Norwegian oil rig workers. Gend Manag. 2008;23(2):137-47. doi: $\underline{10.1108 / 17542410810858330}$

23. Coelho APF, Beck CLC, Silva RM, Prestes FC, Camponogara $\mathrm{S}$, Peserico A. Satisfaction and dissatisfaction in the work of recyclable solid waste segregators : convergent-care research. Rev Bras Enferm. 2017;70(2):384-91. doi: 10.1590/0034-7167-2016$\underline{0325}$

24. Raziq A, Maulabakhsh R. Impact of Working Environment on Job Satisfaction. 2nd Glob Conf Business. Econ Manag Tour. 2015;23:717-25. doi: 10.1016/S2212-5671(15)00524-9
25. Viterbo LMF, Vidal DG, Costa AS, Dinis MAP. Evaluation of the implementation of theTobacco Control Program in workers' health: evidence from an oil industry inBahia, Brazil. In: Proceedings of the International Congress of Health and Well-Being Intervention - ICHWBI2019 [Internet]. Boston: WORK - A Journal of Prevention, Assessment \& Rehabilitation; 2019. Available from: http://workjournal.org/health-and-well-beingintervention-international-congress-abstracts 